$\begin{array}{ll}\text { Received } & : 27 \text { March } 2019 \\ \text { Revised } & : 29 \text { March } 2019 \\ \text { Accepted } & : 11 \text { September } 2019 \\ \text { Published } & : \text { 27 Desember } 2019\end{array}$

\title{
The Role of Student's Language Competence for Producing Negotiation Text
}

\author{
Mega Puspitasari ${ }^{1, a)}$, Andayani $^{1, b)}$, Sarwiji Suwandi, ${ }^{1, c)}$ \\ Pascasarjana Pendidikan Bahasa Indonesia, Universitas Sebelas Maret, Indonesia \\ E-mail: ${ }^{\text {a) }}$ mega.oppo29@gmail.com
}

\begin{abstract}
The student's language competence is a supporting factor that can be used to facilitate communication activities at school or in the community. One of the activities is negotiation. Negotiation needs a language competency for producing negotiating texts, (1) language knowledge including grammer and lexical, (2) strategics competence for finding accurate information on the topic to obtain facts, dare to ask for more than expected, and students must be able to show a firm attitude, and (3) communicative competence including confidence, contextual and effective. Based on these results, the purpose research for describing a Indonesian language competence by students in producing negotiating texts. The research method used is literature study to collect reference data that are relevant to topics from various sources of books, literature and other research results.
\end{abstract}

Keywords: language competence, negotiation text

\begin{abstract}
Abstrak
Kompetensi berbahasa Indonesia yang dimiliki siswa merupakan faktor penunjang yang dapat digunakan untuk mempermudah kegiatan komunikasi di sekolah maupun di masyarakat. Salah satu kegiatan tersebut ialah dalam bernegosiasi. Bernegosiasi membutuhkan peran kompetensi berbahasa siswa untuk dapat menyampaikan maksud dan pesan secara tepat. Peran kompetensi berbahasa Indonesia siswa dalam memproduksi teks negosiasi ini meliputi, (1) pengetahuan bahasa siswa yaitu gramatikal dan leksikal, (2) kompetensi starategi siswa dalam mencari informasi berkenaan dengan topik untuk mengumpulkan fakta, meminta lebih dari yang diharapkan dalam bernegosiasi, dan mempertahankan sikap tegas. (3) kompetensi komunikatif siswa berkaitan dengan rasa percaya diri, kontekstual dan efektif dalam berkomunikasi. Berdasarkan hasil tersebut, penelitian kompetensi berbahasa Indonesia ini dilakukan dengan tujuan untuk mendeskripsikan peran kompetensi berbahasa Indonesia siswa dalam memproduksi teks negosiasi. Metode penelitian yang digunakan ialah studi
\end{abstract}


pustaka untuk menghimpun data referensi yang relevan dengan topik dari berbagai sumber buku, literatur maupun hasil penelitian lainnya.

Kata kunci: kompetensi berbahasa Indonesia, teks negosiasi

\section{PENDAHULUAN}

Manusia dalam hidupnya tidak lepas dari kegiatan negosiasi. Kegiatan ini bisa terjadi dimana saja seperti di rumah, pasar, sekolah dan di tempat lainnya. Di sekolah, negosiasi menjadi salah satu materi dalam pembelajaran bahasa Indonesia kelas $\mathrm{X}$ sekolah menengah atas sederajat. Kemampuan negosiasi siswa dapat tingkatkan dengan melalui pelatihan model pembelajaran pengalaman (Syarvia, 2016). Tujuannya untuk menekankan kepada siswa untuk memahami pengajuan, penawaran, dan persetujuan mengenai suatu objek atau benda yang dinegosiasikan.

Beberapa penelitian yang telah dilakukan membahas mengenai negosiasi seperti Sunarsih (2018) dalam penelitiannya memaparkan rendahnya kemampuan menulis teks negosiasi siswa sehingga dibutuhkan model pembelajaran yang mendukung. Pengaruh model PBL yang telah diteliti Sunarsih berpengaruh positif terhadap hasil menulis teks negosiasi siswa. Nurpadila (2018) dalam penelitiannya juga memaparkan rendahnya kemampuan siswa dalam menulis teks negosiasi sehingga dibutuhkan metode pembelajaran yang inovatif untuk meningkatkan kemampuan menulis siswa. Pengguanaan metode picture and picture dalam penelitian tersebut memeroleh hasil bahwa siswa mengalami peningkatan kemampuan menulis teks negosiasi. Selain menggunakan metode dan model pada penelitian yang telah dilakukan sebelumnya, penulis tertarik untuk meneliti teks negosiasi dengan hal yang berbeda yaitu dengan memerhatikan kompetensi berbahasa yang dimiliki siswa.

Kompetensi berbahasa merupakan hal penting yang dapat menunjang siswa dalam dalam kegiatan negosiasi. Elliot (1996:13-14) mengemukakan bahwa kompetensi berbahasa seseorang meliputi kompetensi linguistik berkenaan dengan hubungan antara pengetahuan struktur bahasa, pengetahuan kaidah bahasa, dan makna bahasa. Wibowo (2017) dalam penelitiannya memaparkan bahwa sebagian besar kemampuan menulis membutuhkan penguasaan kosa kata dan struktur kalimat. Kohesi dan koherensi gramatikal (Angkat, 2017) serta jalinan makna leksikal untuk mencakup luasnya pokok persoalan dalam teks (Wiratno, 2010). Secara garis besar meliputi kompetensi gramatikal dan leksikal yang dibutuhkan dalam memproduksi teks negosiasi.

Selain pengetahuan bahasa, strategi dalam negosiasi juga perlu direncanakan untuk mendukung kompetensi komunikatif (Sudaryanto, 2018). Perencanaan strategi yang tepat mendukung keberhasilan sebuah negosiasi. Rizkiawan (2018) memaparkan strategi untuk mengenali lawan dengan baik dapat mendukung keberhasilan negosiasi secara adil. Meiyanto (1999) memaparkan juga seorang negosiator haruslah mempunyai gaya style agar mempunyai ciri khas tersendiri. Tidak hanya itu, Hamdan (2005) dalam penelitiannya memaparkan bahwa keberhasilan negosiasi bergantung pula pada kepribadian seorang negosiator baik sikap, keyakinan, dan karakteristik personal.

Menunjang strategi dalam negosiasi dibutuhkan pula kompetensi komunikatif. Batubara (2011) memaparkan tidak hanya komunikasi verbal, anggukan kepala dan gerak gerik tubuh membantu mempertegas komunikasi agar mudah dipahami. Halimah 
(2008) memaparkan untuk meningkatkan kompetensi berbahasa dapat dilakukan dengan memberikan kesempatan kepada peserta didik untuk berpartisipasi dalam penggunaan bahasa secara komunikatif di berbagai aktivitas kelas. Mengacu pada penelitian sebelumnya untuk memberikan kesempatan siswa berbahasa secara komunikatif salah satunya dengan bernegosiasi.

Berdasarkan penjabaran di atas, tujuan penelitian ini untuk menjelaskan peran kompetensi berbahasa siswa dalam memproduksi teks negosiasi. Kompetensi berbahasa ini meliputi pengetahuan bahasa, kompetensi strategi, dan kompetensi komunikatif. Ketiga hal tersebut diperlukan dalam memproduksi teks negosiasi.

\section{METODE PENELITIAN}

Penelitian ini menggunakan metode studi pustaka untuk membangun sebuah konsep teori. Teknik pengumpulan data yang digunakan adalah teknik pustaka untuk menghimpun data dari berbagai sumber yang relevan (Subroto, 2007:47). Data dari sumber terkait dideskripsikan, dijelaskan hingga dapat disintesiskan.

\section{HASIL DAN PEMBAHASAN}

Memproduksi teks negosiasi berkaitan dengan dua kegiatan yaitu siswa mengarang teks negosiasi dalam bentuk tulisan dan kegiatan siswa dalam bernegosiasi lisan. Kedua kegiatan tersebut membutuhkan kompetensi berbahasa siswa agar dapat mencapai tujuan negosiasi yang diinginkan. Lehmanni (2007:2) memaparkan kompetensi berbahasa berkenaan dengan kemampuan yang dimiliki manusia dalam hal berbahasa. Kemampuan bahasa ini menentukan sejauh mana seseorang menguasai bahasa. Kemampuan bahasa dalam Dougles (2000:35) dijelaskan dengan language ability atau kemampuan bahasa yang meliputi pengetahuan bahasa dan kompetensi strategi. Kedua hal tersebut diimplementasikan dalam kompetensi komunikatif. Berdasarkan teori tersebut, penulis menentukan kompetensi berbahasa meliputi a) pengetahuan bahasa dalam memproduksi teks negosiasi, b) kompetensi strategi dalam bernegosiasi, dan c) kompetensi komunikatf dalam bernegosiasi. Berikut penjabaran kompetensi berbahasa.

a) Pengetahuan bahasa siswa dalam memproduksi teks negosiasi

Siswa dalam memproduksi teks negosiasi membutuhkan pengetahuan bahasa yang luas agar dapat mengutarakan dengan baik maksud yang diinginkan dalam suatu kegiatan negosiasi. Dougles (2000:35) memaparkan bahwa pengetahuan bahasa terdiri dari gramatikal, tekstual, fungsional, dan sosiolinguitik. Pengetahuan gramatikal meliputi pengetahuan kosakata, morfologi, sintak dan fonologi. Pengetahuan mengenai kosakata berkenaan dengan banyaknya kosakata yang dimiliki setiap orang dan penguasaan terhadap kosakata tersebut. Morfologi berkenaan dengan pembentukan kata, sintak berkenaan dengan kalimat dan fonologi berkenaan dengan pengucapan.

Pengetahuan tekstual meliputi pengetahuan kohesi dan retorika atau organisasi percakapan. Kohesi akan berkenaan dengan pengetahuan dalam menyusun suatu kalimat agar memiliki keterkaitan secara padu dan utuh. Retorika atau organisasai percakapan berkenaan dengan keterampilan berbahasa seseorang secara efektif. Pengetahuan fungsional meliputi pengetahuan ideasional, manipulatif, heuristik, dan imajinatif. Pengetahuan sosiolinguistik meliputi pengetahuan variasi bahasa, register, mengekspresikan idiom, dan referensi budaya. 
Tadayon (2016) dalam penelitiannya memaparkan aspek dari pengetahuan bahasa meliputi pengetahuan gramatikal, pemilihan kosakata, kohesi dan koherensi. Agar dapat memilih kosakata yang tepat, kohesi dan koheren dibutuhkan pula pengetahuan mengenai makna kata.

Berdasarkan pendapat ahli di atas, pengetahuan bahasa yang paling dibutuhkan dalam memproduksi teks negosiasi adalah pengetahuan gramatikal dan makna kata. Pengetahuan gramatikal dan makna kata ini menjadi dasar dalam memproduksi teks negosiasi. Siswa yang memiliki penguasaan gramatikal dan makna kata akan mudah menyusun sebuah teks negosiasi secara kohesi dan koheren.

\section{b) Kompetensi strategi dalam bernegosiasi}

Bernegosiasi juga membutuhkan kompetensi strategi yang tepat agar kedua belah pihak atau orang terkait dalam kegiatan negosiasi memperoleh sebuah kesepakatan. Strategi ini perlu direncanakan dengan maksud agar tujuan yang diinginkan dapat tercapai. Ilo (2003: 97) memaparkan strategi bernegosiasi yaitu 1) utarakan fakta, 2) melakukan kontrol diri, 3) mengatakan yang sebenarnya; 4) meminta lebih dari yang diharapkan; 5) membuat penawaran final, 6) berpendirian teguh 7) mempertanyakan bukti.

Utarakan fakta. Dalam sebuah kegiatan negosiasi tidak bisa jika hanya mengandalkan kalimat-kalimat persuasif. Walaupun mungkin kalimat persuasif tersebut dapat bermanfaat namun tidak dapat memberikan gambaran yang benar atau jelas tentang kondisi yang dialami. Dengan kata lain, pihak yang terkait dalam negosiasi tidak bisa membantah suatu pernyataan jika didukung dengan fakta. Tidak ada kalimatkalimat yang lebih meyakinkan daripada menyajikan fakta dan angka.

Melakukan kontrol diri. Selama negosiasi tawar-menawar berlangsung hindari mengikutsertakan emosional individu ataupun kelompok. Menampilkan emosi dalam bernegosiasi tidak akan mendatangkan manfaat. Kemarahan yang timbul jika tidak mendapatkan suatu kesepakatan yang saling menguntungkan perlu dikontrol agar dapat memberikat waktu lebih untuk kembali melakukan perundingan. Hal ini perlu dilatih secara terus menerus.

Katakan yang Sebenarnya. Seorang negosiator yang sukses adalah negosiator yang memiliki integritas pribadi tidak diragukan. Kalimat-kalimat yang diutarakan dapat diterima oleh pihak lain sebagai sebuah kebenaran dan niat untuk berkomitmen. Hal ini tidak berarti bahwa negosiator harus memberi tahu semua yang diketahui. Menahan informasi dapat dilakukan sesekali. Informasi yang dimiliki harus digunakan secara bijak dan bijaksana agar dapat menjadi strategi tawar-menawar yang baik.

Meminta lebih dari yang diharapkan. Meminta penawaran lebih dari yang di harapkan dapat dijadikan strategi dalam bernegosiasi asalkan penawaran tersebut tetaplah masuk akal. Sebagai negosiator memaparkan kelebihan dari suatu barang yang akan negosiasikan menjadi hal yang sah untuk dijadikan daya tarik. Sehingga daya tarik tersebut dapat dijadikan alasan untuk mengajukan penawaran lebih.

Membuat tawaran final. Pihak yang terkait dalam negosiasi harus mengetahui terlebih dahulu batasan-batasan penawaran dalam suatu barang atau jasa yang ditawarkan. Sehingga tidak ada pihak yang dirugikan. Tawaran final perlu di rencanakan atau diperhitungkan. Hal ini bertujuan agar sebuah negosiasi yang terjadi nantinya mendapat suatu kejelasan baik persetujuan "iya" atau "tidak".

Berpendirian teguh. Jika dalam sebuah negosiasi tidak mendapatkan persetujuan atau penerimaan tawaran, maka harus dikatakan secara langsung disertakan dengan alasan-alasan penguat. Penawaran yang tidak menguntungkan dapat bicarakan terlebih 
dahulu hingga mendapat sebuah kesempatan final. Memiliki pendirian yang teguh diperlukan negosiator untuk mempertahankan penawaran dan permintaan yang terjadi selama proses negosiasi.

Mempertanyakan bukti. Informasi, data, dan dokumen terkait perlu dikumpulkan untuk dianalisis secara kritis. Hal ini sangat penting dalam negosiasi sebagai tambahan informasi yang nantinya dapat digunakan untuk mempertanyakan dan menyangkal bukti apa pun yang dihadirkan selama negosiasi.

Sejalan dengan teori di atas, Hamdan (2015) dalam penelitiannya memaparkan keberhasilan negosiasi dapat dilihat dari aspek keberanian mengggali informasi, kesabaran bertahan, keberanian meminta lebih banyak, integritas menekan solusi, memerhatikan kepentingan bersama, dan dapat menjadi pendengar yang baik melalui diskusi.

Berdasarkan pendapat di atas, kompetensi strategi dalam bernegosiasi perlu direncanakan agar kegiatan negosiasi berhasil memperoleh kesepakatan. Strategistrategi ini meliputi, siswa mencari terlebih dahulu informasi yang akurat mengenai topik agar mendapatkan data fakta dan bukti. Data ini nantinya dapat digunakan sebagai daya tarik penawaran dalam negosiasi. Siswa dalam bernegosiasi harus berani meminta lebih dari yang diharapkan serta siswa harus dapat menampilkan sikap teguh pendirian dengan tidak emosional dan sabar bertahan.

\section{c) Kompetensi komunikatif dalam bernegosiasi}

Tanpa komunikasi tidak akan terjadi sebuah proses negosiasi. Komunikasi yang baik akan mendatangkan keuntungan tersendiri bagi negosiator. Keuntungannya dapat berupa efisiensi waktu maupun materi. kadangkala sebuah negosiasi tidak berujung saling sepakat karena terkendala komunikasi yang tidak bagus. Hal ini perlu diperhatikan ketika akan bernegosiasi. Rickheit (2008: 24) menjelaskan kriteria dalam kompetensi komunikatif yang didasari atas perilaku. Kriteria tersebut meliputi keterampilan komunikasi, efektivitas, dan kesesuaian.

Keterampilan komunikasi. Siswa dalam berkomunikasi memiliki ciri yang berbeda-beda. Ada siswa yang percaya diri ketika berkomunikasi dan ada pula yang malu ketika harus mengungkapkan apa yang dirasa atau diinginkan. Dalam bernegosiasi, kompetensi komunikatif yang dimiliki siswa perlu diasah agar siswa percaya diri ketika melakukan pengajuan, penawaran hingga persetujuan.

Efektivitas. Keefektivitasan komunikasi dalam negosiasi menjadi faktor penting untuk mempermudah mencapai tujuan yang diinginkan. Efektivitas yang dimaksud berhubungan dengan kemampuan untuk mencapai atau menyimpulkan makna pembicara sesuai dengan kondisi yang terjadi. hal ini penting untuk diketahui agar tidak banyak waktu dan konsumsi energi yang terbuang dalam negosiasi. Gagasan efisiensi mengacu pada tingkat efektivitas yang lebih tinggi.

Kesesuaian. Komunikasi yang kompeten harus sesuai dengan situasi yang terjadi. Dalam bernegosiasi, norma atau aturan dapat menjadi landasan agar komunikasi yang terjalin tetap selaras. Siswa dalam bernegosiasi perlu menyampaikan hal-hal yang penting agar tepat sesuai dengan pengajuan atau penawaran yang diinginkan.

Berdasarkan pendapat di atas. Selain siswa memiliki keterampilan komunikasi dengan rasa percaya diri, siswa juga harus efektif dan sesuai dalam berkomunikasi. Efektif berkaitan dengan kemampuan siswa dalam menangkap dan menyimpulkan maksud dari lawan bicara sehingga siswa dapat merespon secara tepat maksud yang diinginkan. Sesuai berarti berkaitan dengan situasi yang terjadi. Jika dalam hal negosiasi siswa harus mengutarakan hal-hal yang sesuai dan dibutuhkan dalam mengajukan suatu 
penawaran.

\section{KESIMPULAN}

Berdasarkan hasil pembahasan dapat disimpulkan bahwa dalam memproduksi teks negosiasi baik tulis maupun lisan membutuhkan peran kompetensi berbahasa. Kompetensi berbahasa ini meliputi a) pengetahuan bahasa dalam memproduksi teks negosiasi berkaitan dengan pengetahuan gramatikal dan makna kata. b) kompetensi strategi dalam bernegosiasi yaitu siswa mencari terlebih dahulu informasi yang akurat mengenai topik agar mendapatkan data fakta dan bukti, siswa dalam bernegosiasi harus berani meminta lebih dari yang diharapkan, dan siswa harus dapat menampilkan sikap teguh pendirian dengan tidak emosional dan sabar bertahan. c) kompetensi komunikatif dalam bernegosiasi yaitu siswa memiliki keterampilan komunikasi dengan rasa percaya, sesuai konteks dan efektif dalam berkomunikasi.

\section{UCAPAN TERIMA KASIH}

Peneliti menyampaikan ucapan terima kasih kepada pembimbing 1 Prof. Dr. Andayani, M.Pd. dan pembimbing 2 Prof. Dr. Sarwiji Suwandi, M.Pd. yang telah membimbing dan memberi semangat tanpa henti dalam menulis artikel tugas akhir. Ucapan terima kasih juga disampaikan kepada teman-teman seangkatan pascasarjana pendidikan bahasa Indonesia Universitas Sebelas Maret, dan tim redaksi Jurnal Aksis atas saran dan masukan untuk perbaikan penulisan artikel ini.

\section{REFERENSI}

Angkat, Polmauli. (2017). Penguasaan Piranti Kohesi dan Koherensi pada Teks Deskripsi Siswa Kelas VII SMP Negeri 2 Sidikalang Tahun Pembelajaran 2016/2017. Jurnal Digilib Unimed.

Batubara, A. K. (2011). Urgensi Kompetensi Komunikasi Pustakawan dalam Memberikan Layanan Kepada Pemustaka. Jurnal Iqra'Perpustakaan dan Informasi. 5, 01 .

Dougles, D. (2000). Assesising languages for spesific pupose. New York: Cambridge University Press.

Elliot. A. J. (1996). Child Language. New York: Cambridge University Press.

Halimah, Lely. (2008). Pemberdayaan Lingkungan sebagai Sumber Belajar dalam Upaya Meningkatakan Kompetensi Berbahasa Indonesia Siswa Kelas 4 SD Laboratorium UPI Kampus Cibiru. Jurnal Pendidikan Dasar. 10.

Hamdan, Y. (2005). Kepribadian Negosiator. MediaTor Jurnal Komunikasi. 8, 1.

Hamdan, Y., Anne R., \& Aziz T. (2015). Kemampuan Negosiasi Penguasaha dalam Meningkatkan Kesepakatan Bisnis. Jurnal Mimbar. 31, 1, 21-30. 
ILO. (2003). Collective Bargaining and Negotiation Skills. Jakarta: Kaontor Perbukuan Internasioanl.

Lehmanni, C. (2007). Linguistic competence: Theory and empiry. Folia linguistica. 41. 223-278.

Meiyanto, S., Soedarjo. (1999). Negosiasi Saat Ini: Semua Menang. Buletin Psikologi. VII, 2.

Nurpadilah, S., Yasri, F., \& Cucu, K. (2018). Kemampuan Menulis Teks Negosiasi Dengan Menggunakan Metode Picture And Picture Di SMK. Parole Jurnal Pendidikan Bahasa dan Sastra Indonesia, 1, 4.

Rickheit, G. (2008). The concept of communicative competence. Handbook of communication competence. Berlin: Walter de Gruyter GmbH \& Co. KG, D10785.

Rizkiawan, Z. (2018). Analisis Strategi Negosiasi Penjualan pada Auto2000 Kertajaya. Jurnal Repository Universitas Airlangga.

Subroto, E. (2007). Pengatar Metode Penelitian Linguistik Struktural. Surakarta: LPP (Lembaga Pengembangan Pendidikan) UNS Press.

Sudaryanto. (2018). Tiga Fase Perkembangan Bahasa Indonesia (1928-2009):

Kajian Linguistik Historis. Aksis: Jurnal Pendidikan Bahasa dan Sastra Indonesia 2(1). 1-16. doi: doi.org/10.21009/AKSIS.020101.

Sunarsih, E., Suci A., \& Lili. (2018). Pengaruh Model Pembelajaran Problem Based Learning terhadap Hasil Belajar Menulis Teks Negosiasi Siswa Kelas X SMA Negeri 1 Singkawang Tahun Ajaran 2017/2018. Jurnal Pendidikan Bahasa dan Sastra Indonesia, 3, 2, 89-93.

Syarvia, 2016. (2016). Rancangan Program Pelatihan untuk Meningkatkan Self Efficacy Negosiasi pada Siswa SMK. Psympathic Jurnal Ilmiah Psikologi. 1, 1, 78-86.

Tadayon, F., \& Hamdollah, R. (2016). Using grounded theory to validate Bachman and Palmer's (1996) strategic competence in EFL graph-writing. Article Langguage Testing in Asia (Springer Open), 6:8.

Wibowo, B., Sukardi., Purnomo. (2017). Hubungan Penguasaan Struktur Kalimat dan Penguasaan Kosakata dengan Keterampilan Menulis Narasi. Joyful Learning Journal. 6, 2.

Wiratno, Tri. (2010). Realisasi Makna Tekstual pada Artikel Jurnal Ilmiah dalam bahasa Indoensia. Jurnal Ilmiah Nasional. 28, 2. 